\title{
Ergonomic Environment, Information and Communication Technology (ICT) and Secretarial Efficiencies in Tertiary Institutions in Ekiti State, Nigeria
}

\author{
Felicia Bosede Kehinde Fasae* Janet Kehinde Ajayi \\ Business Education Department, College of Education, Ikere-Ekiti, Ekiti State, Nigeria
}

\begin{abstract}
Ergonomic environment, information and communication technology (ICT) and secretarial efficiencies in tertiary institutions in Ekiti State were investigated. The population consisted of all secretarial staff and executives/directors in all tertiary institutions while the sample was 180 respondents randomly selected from three tertiary institutions. The research instrument was questionnaire, validated with a reliability co-efficient of 0.77 . Data collected were analyzed using frequency counts and simple percentages for the research question while the hypothesis was tested using Pearson Moment Correlation Coefficient at 0.05 level of significance. Findings show that the physical environments of the institutions are conducive for work and some necessary facilities that could aid the efficiency of secretarial staff are provided but inadequate. It was concluded that good working environment is indispensable in today's workplace for the efficiency and effectiveness of secretarial workers. It was suggested that efforts must be made to design jobs that help employees reduce and break up their sitting time, among others. Keywords: Ergonomics, Secretaries, Efficiency, Work Environment, ICT.
\end{abstract}

DOI: $10.7176 / \mathrm{EJBM} / 11-23-07$

Publication date: August $31^{\text {st }} 2019$

\section{Introduction}

Office work is rapidly changing, as new developments in computer technology which make jobs easier are emerging. According to Kumah, Akuffo, Affram, Ankamah and Osae (2016), its emergence presents occupational health and safety problems for both management and employees.

Organisations have the obligations to provide safe working environments for workers in order to improve their efficiencies. This is because a poor working environment can affect the health of the worker which will in turn affect his/her productivity. Niu (2010), citing Frymoyer and Mooney, (1986), agreed that a number of situations within the workplace are conjectured to contribute to the increasing magnitude of musculoskeletal disorders (MSDs) suffered by workers, including postural stress from prolonged sitting, standing, or awkward position; stereotyped and repetitive tasks leading to chronic injury; peak overload injuries to the axial or peripheral skeleton; environmental factors; and psychosocial system.

A workplace or work environment is a place where somebody works, for example, a factory or office (Microsoft Encarta, 2006). An office work environment comprises of a place designed for performing all productive office tasks and as such it is a combination or integration of physical location of an office, the interior and exterior surroundings, office layouts, work organisation, office temperature and humidity, light intensity, work facilities, as well as the right training and awareness of how to make effective use of these work facilities so that that they do not inflict harm on the user and general awareness of other aspects of office safety and health (Ekstrand, Mari, and Sigrid Damman. (2016). Niu (2010) observed that changes in the working environment in recent decades have both created new ergonomic related health problems and exacerbated existing ones among the different working populations, hence, musculoskeletal complaints are commonly reported among office workers worldwide and these can have detrimental effects on workers' health and productivity.

Modern information and communication technology (ICT) has contributed a lot in improving the professional competence of the secretary because jobs can now be accurately carried out: the man-hour per unit of production of office work has reduced while the level of skill of employees has increased. This is because secretarial staff are no longer sedentary workers in the office who sit behind antiquated typewriters waiting for order from their boss. Information technology has exposed secretaries to the world of information processing and disseminating within seconds and has given them more opportunities for growth (Afeidia, 2006). However, Abdu, Seow and Sulzakimin (2017) discovered that complaints of arms neck and shoulders (CANS) pains are common issues among the typists, secretaries, personal assistants, computer users and other related clerical activities in the governmental offices in Nigeria. This issue of work related musculo-skeletal complaints or disorders has a devastating, negative impacts on the overall workers' output and the economy in general as a result of incessant absenteeism and loss of workers' productivity.

Ergonomics is about design and, literally translated, means human factors. It deals with how human beings fit into the work environment. Scientific information about our environment is analysed and the best way for us to use that space is then designed. The Occupational Health and Safety Managers (2009) assert that those who 
must spend long periods in a seated position on the job such as taxi drivers, call centre professionals and office workers, are at risk for injury and a variety of adverse health effects. The most common injuries occur in the muscles, bones, tendons and ligaments, affecting the neck and lower back regions. This is because prolonged sitting can: reduce body movement making muscles more likely to pull, cramp or strain when stretched suddenly; cause fatigue in the back and neck muscles by slowing the blood supply and put high tension on the spine, especially in the low back or neck; cause a steady compression on the spinal discs that hinders their nutrition and can contribute to their premature degeneration.

In the observations of Juul-Kristensen, and Jensen (2018), when organising computer work, it is important to allow for physical variation with other work tasks, thereby avoiding working with the computer during all the work time, and further to consider the worker's own influence on the speed of work. Musculoskeletal symptoms are common among office workers, and at the same time the duration of computer work in a modern occupational setting has increased dramatically. According to Salik and Özcan (2004) a work-related musculoskeletal disorder (WRMD) is defined as a musculoskeletal injury that results from a work-related event. This may result in lost work time, work restriction, or transfer to another job (Nyland \& Grimmer, 2003). Furthermore, according to Crowl (2007), principles of office ergonomics emphasize that, in designing work places, furniture, office layout and equipment, it is important that such designs take human factor into considerations so as to make work easier and safer for the workers (. In this case, in order to have ergonomic designs of work place facilities, it is also necessary to consider the features, sizes, biological make up and the capability of workers who will use them.

\subsection{Problem}

Observation shows that secretaries are the worst hit by MSDs because of the nature of their job which is highly demanding. It has been observed that work environments are not conducive for secretaries. Abdu, et al (2017) noted that despite what has been said about the importance of having ergonomic designs of work place facilities, it is still not enough to prevent the prevalence and complaints of work related musculo-skeletal disorders. Bakare (2009) observed that it is not uncommon to go into an office and see the secretary or receptionist working on a computer placed on a regular reading table and sitting on a chair that would look more at home around a dining table. He opines that obvious ergonomic problems will manifest over time since neither the table nor the chair was originally designed for the use to which it is now being put. Furthermore, provision of necessary facilities that could aid effectiveness and efficiencies of secretaries is inadequate.

\subsection{Purpose}

The study investigated ergonomic environment, ICT and secretarial efficiencies in tertiary institutions in Ekiti State. It sought to investigate the extent to which organisations are concerned with the ergonomic environment of secretaries by making adequate provision of necessary facilities to enhance their efficiencies and tried to find out if there was any relationship between the ergonomic environment of secretaries and their efficiencies and health at work.

1.3 Research Question: To what extent are organizations concerned with the ergonomic environment of secretaries by making adequate provision of necessary facilities to enhance their efficiencies?

1.4 Research Hypothesis: Is there any relationship between the ergonomic environment of secretaries and their health and efficiencies at work?

\section{Literature Review}

\subsection{Ergonomic Environment}

Ergonomics is a field which integrates knowledge derived from the human sciences in particular anatomy, physiology and psychology to match jobs, systems, products and environments to the physical and mental abilities and limitations of workers. Ergonomics stresses fitting the job to the worker as compared to the more usual practice of obliging the worker to fit the job. The aim of ergonomics is to optimize, first and foremost, the comfort of the worker, as well as his or her health, safety and efficiency (Niu, 2010).

Ergonomically designed workstations have direct bearing on the comfort and safety of office computer users. Tremendous usage of computers in most offices of emerging economies have however, not seen accompanying applications of ergonomics in the design of computer workstations despite the numerous benefits. Injuries and discomforts therefore have higher propensity to occur since most offices formally designed for paper based work now accommodate computer workstations, without corresponding redesigning. Kumah, et al (2016) study assessed computer workstation designs in administrative offices at Kwame Nkrumah University of Science and Technology, Ghana, with the aim of creating awareness of ergonomics and its application among administrative office computer users. The study found that all respondents suffer one form or another of visual 
discomfort as a result of prolonged computer usage, prominent amongst which were neck, back and shoulder pains, eyestrain, burning and itchy, headache and red eyes.

Ergonomic environment is the design of a workplace and workstation that make work easy for employees. Since computers, according to Birbal and Taylor (2004), are a hugely important part of human work as people rely on data gathering and analysis in industries to give them a competitive edge, this type of task is labour intensive, requiring hours of concentrated and repetitive work on the computer by individual operators. After a few years in this type of environment, a worker can suffer from a range of health problems such as repetitive strain injury (RSI), Computer Vision Syndrome (CVS). Tenosynovitis (teno), muscular skeletal and postular problems, work-related upper limb disorder, reproductive hazards, lower back pain and so on. Therefore, many of these problems can be eliminated or reduced if careful attention is paid to a person's work routine and ergonomics.

Ergonomic environment is therefore very important in order to reduce stress in the work place. A work place is a complete working environment, including the heating, lighting, decoration and so on. A good work place design can reduce or even eliminate many of the health complaints. A research, according to Erwart (2008), shows that when the furniture of some employees were improved, the productivity increased by $20 \%$. The Department of Education, Training and the Arts (2008) advised that room temperature should be okay, well ventilated and lighted, well decorated, well painted, furniture big enough depending on the job design, should not be clustered, should be high enough, suitable chair (swivel), top of desk should be smooth. Accordingly, employers have legal obligations to protect their workers from health hazards since health of workers is irretrievably bound to their productivity. Eye defects should be checked for and taken care of; there must be adequate health and safety training; health entitlements should be provided; security-emergency marks and fire extinguisher provided.

Tafese, Nega, Getasew and Erku (2018) study assessed knowledge and practice of secretaries and data processing workers on computer ergonomics with a total of 260 study participants and found that the level of good knowledge and practice of the community was below mean value as more than half of the participants heard about importance of computer ergonomics for the wellbeing of their health. Even if they had good knowledge they were not practically safe since it has a score of below the mean practice. Akinbinu \& Mashalla (2013) study revealed that the number of people suffering from musculoskeletal conditions has increased by 25 percent over the past decade and these conditions make up $2 \%$ of the global disease burden.

Furthermore, The Department of Education, Training and the Arts (2008) says equipment also has to do with ergonomic environment. The VDU radiation affects people's eyes and so should be tilted to one's comfort. The keyboard should be high enough and soft. The mouse should be well placed as to allow easy movement of the wrist and fingers. Also, software should be user friendly. The systems should be noise proof. Doors should not be banging. Beautiful plants should be planted in the environment to give fresh air. Jobs design must be in such a way as to have a break.

The department further outlined the correct posture of a person working at the computer as:

- Feet are rested firmly on the floor or footpad

- Thighs are fully supported by chair seat except for a two-finger width space behind the knee

- Curve of lower back is supported by chair back

- Elbows, hips and knees are bent at approximately 90 degrees

- Shoulders are relaxed so shoulder blades are free to move

- Forearms are parallel to the floor or sloping slightly downwards to the desktop

- Wrists are straight and not bent up, down or to the side. Note: Wrist supports help to maintain natural, not extreme wrist position when working with a mouse. Wrist supports to be soft

- Top of screen is at eye level or slightly below, about arm length straight in front of your eyes

- Glare and reflection of the screen are avoided by changing angle and orientation of the screen

- Neck is relaxed and balanced; chin is not poking upwards.

Correct posture can be complemented with correct study behaviour as follows:

- Take short breaks while keying to relax your hands and prevent fatigue

- Take longer breaks every 30-60 minutes to get up, walk, and do exercises or another task to move your body and to increase your blood circulation

- Take time to look further away to help your eye muscle to relax

- Take breaks to drink water and have nutritious meals

- Change position often while obeying the same basic principles of correct posture.

\subsection{Information and Communication Technology (ICT) and Secretaries}

Information Communications Technology - or technologies (ICT) is an umbrella term that includes all technologies for the communication of information, encompassing: any medium to record information (whether paper, pen, magnetic disk/ tape, optical disks - CD/DVD, flash memory etc. etc.); technology for broadcasting information - radio, television,; any technology for communicating through voice and sound or images - 
microphone, camera, loudspeaker, telephone to cellular phones. At present, it is apparently culminating to information communication with the help of Personal Computers (PCs) networked through the Internet through information technology that can transfer information using satellite systems or intercontinental cables. Indeed, information technology (IT) has become a kind of a hub for communicating information, most often using computers. But, with an expanding fraction of human population getting empowered to share information it may not continue to be so (Wikipedia, 2008).

Yekini (2014) sees Information Technology Communication as the convergence of audio-visual, telephone and computer networks through a link system. It is a combination of all these elements, capped by a vision on how technology can help an organization to reach its goals. Furthermore, (ICT) is often used as an extended synonym for information technology (IT), but is a more specific term that stresses the role of unified communications and the integration of telecommunications (telephone lines and wireless signals), computers as well as necessary enterprise software, middleware, storage, and audio-visual systems, which enable users to access, store, transmit, and manipulate information. It is thus a powerful collection of elements which include computer hardware, software, telecommunication networks, workstations, robotics and smart chips, which is also at the root of information systems.

Tafese, et. al. (2018), citing Jamison, Breman, Measham, Alleyne and Claeson (2006) noted that computers are an integral part of life and that in every sphere of life, the dependence on computers is ever increasing. In the absence of a good ergonomic design, extended work for prolonged periods can adversely affect not only vision, but also leads to musculoskeletal disorders. Yekini (2014) asserted that a computer may harm users if they use it for long hours frequently. Computer users are also exposed to bad posture, eyestrain, physical and mental stress. In order to solve the health problems, an ergonomic environment can be introduced. For example, an ergonomic chair can reduces back strain and a screen filter is used to minimize eye strain. Khan, Surti, Rehman and Ali (2012) opined that computer ergonomics is used to design an appropriate computer workstation and decrease computer related health problems through optimizing the association between environment and the person where the concern to assemble things at the workstation.

A secretary is an employee who does clerical and administrative work in an office for a person or organization (Encarta, 2009). The introduction of modern information and communication technology to business organizations has significantly changed the mode of operations of secretarial workers. Buseni (2013) opined that the information and communication technology in the 21 st century have revolutionized all profession worldwide including the secretarial practice and that the secretarial function, though a supportive function, requires a large amount of initiative, tact and resourcefulness to succeed. He noted further that the quality of secretaries available is a function of reliable and acceptable reporting framework that will improve productivity in the public sector. This can only be achieved through an effective and efficient human resource development structure.

Aina (2003) sees the raw materials of an office as information and the responsibility of the office is like that of a clearing house receiving and sending out information, processing and storing facts in various forms, modern information and communication technology, is an effective resource to secretarial workers as it enhances their level of performance. With these technologies, secretaries have access to accurate, up-to-date and timely information.

According to Adedoyin, Idowu, Adagunodo, \& Idowu (2004), computer related musculoskeletal disorders affect millions of computer users in developed nations. With proliferation of computer systems in the developing nations like Nigeria, the associated musculoskeletal pain is yet to be investigated. The result shows that low back pain and neck pain were found to be the highest pain complaint with $74 \%$ and $73 \%$ respectively. $67 \%$ of the respondents complained of wrist pain, followed by finger pain $(65 \%)$, shoulder pain $(63 \%)$ and general body pain $(61 \%)$. The knee and foot pains were the least complaints reported with $26 \%$ and $25 \%$ respectively. In terms of pain severity, low back pain, finger pain, neck pain and shoulder pain are rated to be moderate, while all other joints were said to be of mild pain. The results of this study indicated that low back pain, neck pain and upper limbs are the common disorders complaints among the users. The cause of the pain may be attributed to bad ergonomics among the users.

Widespread computer use has created new physical hazards, including repetitive strain injuries (RSI), like tendinitis and carpal tunnel syndrome, for office personnel. Tuller (2000), citing Stroud, a spokesman for the International Association of Administrative Professionals, says that advances in technology and changes in corporate structure mean that secretaries may be working under more pressure than ever before. Accordingly, in today's offices, everyone wants things done faster and cheaper, and a lot of offices are downsized to the point that office personnel are taking on more advanced and complicated roles.

Triano and Nancy (2007) claimed that prolonged static posture is the enemy of the back. The healthy body can only tolerate staying in one position for about 20 minutes. That is why sitting on an airplane, at a desk in an office chair, or at a movie theatre becomes uncomfortable after a short time. Standing in one place, such as standing on a concrete floor at an assembly line for extended periods of time tends to cause back pain. Holding the same position slowly diminishes elasticity in the soft tissues (muscles ligaments and tendons in the back). Then, stress 
builds up and causes back discomfort and/or leg discomfort. They agree that there is the need to change positions frequently, that is, just move - stand or sit, stretch, take a short walk. After returning to the standing or sitting posture, use an alternate posture for just a few moments and some of the tissue elasticity needed to protect the joints will return. There is therefore the need for sound ergonomic practices in work environments for secretaries to be able to perform excellent work and increase their efficiencies.

\subsection{Ergonomic Hazards in the Workplace}

Ergonomics is the science of fitting jobs to workers by taking into account the requirements of the job and peoples' physical and mental capacities. Knowledge and practice about computer ergonomics helps employers and data processing workers to develop strategies that used to reduce the effects of poor computer ergonomics in the selected population Tafese, et. al. (2018). Basically, musculoskeletal disorders arise from damage to muscles and joints. They are not confined to particular industries or types of people. Work-related problems are often caused by poor workplace or job design which can lead to: poor working positions; too much bending, stretching or effort required; high levels of repetition and but not limited to difficult manual handling of tasks. The back, neck, shoulders and upper limbs are particularly at risk. Such health problems may be identified by injuries to backs and limbs, employee complaints and rest stops, poor product quality and/or individual performance, etc. Some musculoskeletal disorders develop slowly and it is important to catch them early. Reporting of aches and pains should be encouraged so that appropriate action can be taken.

According to US Department of Labour (Occupational Safety and Health Administration, (2010), when analyzing jobs or work tasks that may be associated with MSDs, conditions to consider may include, but are not limited to awkward postures, which might include prolonged work with hands above the head or with the elbows above the shoulders; prolonged work with the neck bent; squatting, kneeling, or lifting; handling objects with back bent or twisted; repeated or sustained bending or twisting of wrists, knees, hips or shoulders; forceful and repeated gripping or pinching. Also, prolonged repetitive motion, which might include keying, using tools or knives, packaging, handling, or manipulating objects. Contact Stress, which might include repeated contact with hard or sharp objects, like desk or table edges. Vibration, which might include: overuse of power hand tools.

Since the price of computers has gone down considerably in Nigeria, the number of users has greatly increased as many organizations and individuals could afford them. Consequently, complaints of musculoskeletal pain are daily reported in the physical therapy department (Adedoyin et al, 2004). They studied the relationship between upper limb symptoms and keyboards users and concluded that the use of keyboards was associated with discomfort at the shoulder and wrist or hand. All frequent computer users usually feel the twinges that results from an entire day of mousing and typing causing aches and pain around the fingers (Hedge, 2000). These symptoms are the clinical features usually linked with the onset of carpal tunnel syndrome.

According to The Occupational Health and Safety Managers (2009), employees, who for years spend most of their working time seated, may experience other, less specific adverse health effects such as decreased fitness, reduced heart and lung efficiency, and digestive problems. Recent research has identified too much sitting as an important part of the physical activity and health equation, and suggests we should focus on the harm caused by daily inactivity such as prolonged sitting. In addition, people who interrupted their sitting time more often just by standing or with light activities such as housework, shopping, and moving about the office had healthier blood sugar and fat levels, and smaller waistlines than those whose sitting time was not broken up. Injuries resulting from sitting for long periods are a serious occupational health and safety problem and are expected to become more common with the continuing trend toward work in a sitting position.

Niu (2010), citing Snook, (1987) asserts that estimations have shown that at least $50 \%$ of all work-related MSDs among the working population could be prevented by appropriate ergonomic job design. Preventing ergonomic problems and MSDs and obtaining optimal performance can be achieved when equipment, workstations, products and working methods are designed according to human capabilities and limitations by applying the principles of ergonomics. The most effective intervention programmes seem to be those with multiple, coordinated activities, including workstation improvement, provision of adjustable furniture, training to facilitate workers' knowledgeable adjustment of work-stations and work schedules, and enhanced medical surveillance and management systems (Bernacki, Guidera, Scharefer, Lavin and Tsai (1999).

Niu (2010) notes however, that applying ergonomic principles, is beneficial, not only to the workers buy the benefits to employers are equally significant. Healthy employees can be nearly three times more productive than those in poor health and that these benefits to the workers and employers are both visible and measurable.

A user centered approach to impart knowledge of the anatomy and physiology of the body in addition to the nature of work and workstation design is needed to enable individuals to organize their workplace to prevent various health hazards by adjusting proper height of the seat, working posture, proper use of armrest, backrest, straight alignment of the wrist and the elbow and positions on keyboard can prevent various health hazards [Jamison, et. al. (2006).

This study was based on socio-technical approach as postulated by Pasmore (1988). The socio-technical 
systems approach is based on the premise that every organization consists of the people, the technical system and the environment. People (the social system) use tools, techniques and knowledge (the technical system) to produce goods or services valued by consumers or users (who are part of the organization's external environment). Therefore, an equilibrium among the social system, the technical system and the environment is necessary to make the organization more effective. The environment must be conducive and equipment user friendly.

\section{Method}

The design for this study was a survey research design. The population consisted of all secretarial staff and executives/directors in three institutions of learning in Ekiti State. The sample was 180 respondents randomly selected from among the secretarial staff and executives/directors in the three institutions. The research instrument for the study was a modified 4-point Likert-type questionnaire tagged "Ergonomic Environment, ICT and Secretarial Workers in Tertiary Institutions in Ekiti State (EEICTSWTIES)". A total of 20 questions were used to collect relevant data from the two different categories of respondents. The instrument was validated by research and secretarial experts for face and content validities. The instrument was subjected to test-re-test method of reliability with a co-efficient of 0.77 . Data collected were analyzed using frequency counts and simple percentages to answer the research question while the hypothesis was tested using Pearson Moment Correlation Coefficient to test the relationship between variables at 0.05 level of significance.

\section{Results}

Research Question: To what extent are organizations concerned with the ergonomic environment of secretaries by making adequate provision of necessary facilities to enhance their efficiencies?

Table 1: Responses on Provision of Necessary Facilities in the Workplace

\begin{tabular}{|c|c|c|c|c|c|}
\hline \multirow[b]{2}{*}{$\mathbf{S} / \mathbf{N}$} & \multirow[b]{2}{*}{ ITEMS } & \multicolumn{2}{|c|}{ EXECUTIVES } & \multicolumn{2}{|c|}{ SECRETARIES } \\
\hline & & A & D & A & D \\
\hline & $\begin{array}{l}\text { The physical environment of your workplace has the following } \\
\text { characteristics: }\end{array}$ & & & & \\
\hline 1. & - $\quad$ good ventilation & $\begin{array}{l}63 \% \\
24\end{array}$ & $\begin{array}{l}37 \% \\
14\end{array}$ & $\begin{array}{l}57 \% \\
48\end{array}$ & $\begin{array}{l}43 \% \\
36\end{array}$ \\
\hline 2. & - $\quad$ too cold weather & $\begin{array}{l}42 \% \\
16\end{array}$ & $\begin{array}{l}58 \% \\
22\end{array}$ & $\begin{array}{l}26 \% \\
22\end{array}$ & $\begin{array}{l}74 \% \\
62\end{array}$ \\
\hline 3. & - $\quad$ too hot weather & $\begin{array}{l}32 \% \\
12\end{array}$ & $\begin{array}{l}68 \% \\
26\end{array}$ & $\begin{array}{l}38 \% \\
32\end{array}$ & $\begin{array}{l}62 \% \\
52\end{array}$ \\
\hline 4. & - $\quad$ humidity & $\begin{array}{l}58 \% \\
22 \\
\end{array}$ & $\begin{array}{l}42 \% \\
16 \\
\end{array}$ & $\begin{array}{l}50 \% \\
42 \\
\end{array}$ & $\begin{array}{l}50 \% \\
42 \\
\end{array}$ \\
\hline 5. & - $\quad$ lighting & $\begin{array}{l}63 \% \\
24\end{array}$ & $\begin{array}{l}37 \% \\
14\end{array}$ & $\begin{array}{l}48 \% \\
40\end{array}$ & $\begin{array}{l}52 \% \\
44\end{array}$ \\
\hline 6. & - noise & $\begin{array}{l}32 \% \\
12\end{array}$ & $\begin{array}{l}68 \% \\
26\end{array}$ & $\begin{array}{l}33 \% \\
28\end{array}$ & $\begin{array}{l}67 \% \\
56\end{array}$ \\
\hline 7. & - vibration & $\begin{array}{l}47 \% \\
18\end{array}$ & $\begin{array}{l}53 \% \\
20\end{array}$ & $\begin{array}{l}40 \% \\
34\end{array}$ & $\begin{array}{l}60 \% \\
50\end{array}$ \\
\hline 8. & - beautiful plants & $\begin{array}{l}84 \% \\
32\end{array}$ & $\begin{array}{l}16 \% \\
6\end{array}$ & $\begin{array}{l}71 \% \\
60\end{array}$ & $\begin{array}{l}29 \% \\
24\end{array}$ \\
\hline & $\begin{array}{l}\text { The following type of furniture/equipment are made available in } \\
\text { your workplace }\end{array}$ & & & & \\
\hline 9. & - wooden chair & $\begin{array}{l}68 \% \\
26 \\
\end{array}$ & $\begin{array}{l}32 \% \\
12 \\
\end{array}$ & $\begin{array}{ll}55 \% \\
46\end{array}$ & $\begin{array}{l}45 \% \\
38\end{array}$ \\
\hline 10. & $\begin{array}{l}\text { - adjustable chair with } \\
\text { armrest }\end{array}$ & $\begin{array}{l}47 \% \\
18\end{array}$ & $\begin{array}{l}53 \% \\
20\end{array}$ & $\begin{array}{l}52 \% \\
44\end{array}$ & $\begin{array}{l}48 \% \\
40\end{array}$ \\
\hline 11. & $\begin{array}{l}\text { - adjustable chair } \\
\text { without arm rest }\end{array}$ & $\begin{array}{l}68 \% \\
26\end{array}$ & $\begin{array}{l}32 \% \\
12\end{array}$ & $\begin{array}{l}50 \% \\
42 \\
\end{array}$ & $\begin{array}{l}50 \% \\
42\end{array}$ \\
\hline 12. & - Executive table & $\begin{array}{l}74 \% \\
28 \\
\end{array}$ & $\begin{array}{l}26 \% \\
10 \\
\end{array}$ & $\begin{array}{l}64 \% \\
54 \\
\end{array}$ & $\begin{array}{l}36 \% \\
30 \\
\end{array}$ \\
\hline 13. & - Ordinary table & $\begin{array}{l}68 \% \\
26\end{array}$ & $\begin{array}{l}32 \% \\
12\end{array}$ & $\begin{array}{l}57 \% \\
48\end{array}$ & $\begin{array}{l}43 \% \\
36\end{array}$ \\
\hline 14. & - Foot rest & $\begin{array}{l}74 \% \\
28\end{array}$ & $\begin{array}{l}26 \% \\
10\end{array}$ & $\begin{array}{l}43 \% \\
36\end{array}$ & $\begin{array}{l}52 \% \\
44\end{array}$ \\
\hline 15. & - Document holder & $\begin{array}{l}58 \% \\
22\end{array}$ & $\begin{array}{l}42 \% \\
16\end{array}$ & $\begin{array}{l}52 \% \\
44\end{array}$ & $\begin{array}{l}48 \% \\
40\end{array}$ \\
\hline
\end{tabular}




\begin{tabular}{|c|c|c|c|c|c|}
\hline 16. & - Monitor stands & $\begin{array}{l}53 \% \\
20\end{array}$ & $\begin{array}{l}47 \% \\
18\end{array}$ & $\begin{array}{l}50 \% \\
42\end{array}$ & $\begin{array}{l}50 \% \\
42\end{array}$ \\
\hline 17. & - $\quad$ Monitor arms & $\begin{array}{l}37 \% \\
14\end{array}$ & $\begin{array}{l}63 \% \\
24\end{array}$ & $\begin{array}{l}48 \% \\
40\end{array}$ & $\begin{array}{l}52 \% \\
44\end{array}$ \\
\hline 18. & - Screen filter & $\begin{array}{l}53 \% \\
20\end{array}$ & $\begin{array}{l}47 \% \\
18\end{array}$ & $\begin{array}{l}50 \% \\
42 \\
\end{array}$ & $\begin{array}{l}50 \% \\
42 \\
\end{array}$ \\
\hline 19. & - $\quad$ Fire extinguisher & $\begin{array}{l}42 \% \\
16\end{array}$ & $\begin{array}{l}58 \% \\
22\end{array}$ & $\begin{array}{l}57 \% \\
48\end{array}$ & $\begin{array}{l}43 \% \\
36\end{array}$ \\
\hline 20. & $\begin{array}{l}\text { There is the adequate provision of medical facilities for } \\
\text { secretaries. }\end{array}$ & $\begin{array}{l}68 \% \\
26\end{array}$ & $\begin{array}{l}32 \% \\
12\end{array}$ & $\begin{array}{l}55 \% \\
46\end{array}$ & $\begin{array}{l}45 \% \\
38\end{array}$ \\
\hline
\end{tabular}

Decision Rule: $50 \%$ taken as pass marks.

In the table above, for items $1-8$, responses from both executives and secretaries show that they agree with the fact that the physical environment of their workplace is well ventilated, lighted, decorated with beautiful plants and free from noise or vibration. They also disagreed that the weather in the workplace is too hot or too cold. This implies that the temperature in the rooms are controlled, using natural ventilation, fans or air conditioners.

Furthermore, items 9, 11, 12, 13, 15, 16 and 20 reveal that wooden chairs, adjusted chair without arm rest, executive table, ordinary table, document holder, monitor stands and adequate provision of medical facilities rated above $50 \%$. This means that some necessary facilities are provided which make the physical environment of the institution conducive for work and will hence aid productivity and efficiency. However, the provision is inadequate. The result also shows that the institutions are concerned with the ergonomic environment of their workers but still need to improve on the provision of necessary facilities.

Hypothesis:There is no significant relationship between the ergonomic environment and the secretaries/administrative assistants' health at work.

Table 2: Relationship between the provision of necessary facilities in the workplace and the secretaries/administrative assistants' health at work

\begin{tabular}{|l|l|l|}
\hline Variables & $\begin{array}{l}\text { Provision of necessary facilities in the } \\
\text { workplace }\end{array}$ & $\begin{array}{l}\text { Secretaries' health at } \\
\text { work }\end{array}$ \\
\hline $\begin{array}{l}\text { Provision of necessary facilities in the } \\
\text { workplace }\end{array}$ & 1 & 0.206 \\
\hline $\begin{array}{l}\text { Secretaries' efficiencies and health at } \\
\text { work }\end{array}$ & & 1 \\
\hline
\end{tabular}

Significance Level $p \leq 0.05$

The table above reveals that there is a significant positive relationship between the provision of necessary facilities in the workplace and secretaries' efficiencies and health $(\mathrm{r}=0.206)$. Therefore, the null hypothesis which states that there is no significant relationship between the ergonomic environment and the secretaries/administrative assistants' efficiencies and health at work is rejected. This implies that the ergonomic environment has impact on secretaries' efficiencies and health at work.

\section{Discussion}

The results revealed that there is a significant positive relationship between the provision of necessary facilities in the workplace and secretaries' efficiencies and health at work. This is because the physical environment of the workplace is well ventilated, lighted, decorated with beautiful plants and free from noise or vibration. They also agreed that the weather in the workplace is normal, implying that the temperature in the rooms is controlled, using natural ventilation, fans or air conditioners. This is in line with Niu (2010) that at least 50\% of all work-related MSDs among the working population could be prevented by appropriate ergonomic job design and that preventing ergonomic problems and MSDs and obtaining optimal performance can be achieved when equipment, workstations, products and working methods are designed according to human capabilities and limitations. Also, applying ergonomic principles, is beneficial, not only to the workers but the benefits to employers are equally significant. Healthy employees can be nearly three times more productive than those in poor health and that these benefits to the workers and employers are both visible and measurable.

However, adequate relevant and important facilities such as adjustable chair with arm rest and foot rest need to be provided for secretaries in particular to be in line with Bakare (2009) that working on a computer placed on a regular reading table and seating on a chair that would look more at home around a dining table would obviously make ergonomic problems to manifest over time since neither the table nor the chair was originally designed for the use to which it is now being put.

\section{Implication to Research and Practice}

If organisations are aware that taking proactive steps to prevent employees' incurring injuries will cost less than 
spending on ill health, they are likely to utilize the results of researches which will also lead to further researches. To practice, ergonomic awareness helps secretarial staff to take proactive steps in preventing injuries which could hamper their health and consequently, their efficiencies and effectiveness and that of the organisation.

\section{Conclusion/Suggestions}

Good working environment is indispensable in today's workplace. Ergonomic environment is very important to the efficiency and health of office workers, especially, secretaries. When the environment is well organized, it could help to increase workers' productivity and prevent injuries at work. Furthermore, training in ergonomic practice could help to improve employee's knowledge and, consequently, their health and efficiencies, to the wellbeing of the organisation.

Based on the findings of the study, it was suggested that since prolonged sitting can be a health risk, efforts must be made by institutions to design jobs that help people reduce and break up their sitting time. There should be opportunity to allow for physical variation with other work tasks, thereby avoiding working with the computer during all the work time, and further to consider the worker's own influence on the speed of work.

\section{Acknowledgements}

The researchers are indebted to secretarial and executive staff of the tertiary institutions used for the study for the support provided in terms of expertise and moral support during the research. We also appreciate authors cited in this work.

\section{References}

Abdu Gambo, Seow Ta Wee, Sulzakimin Mohamed (2017). Creating office ergonomic awareness among the staff of Katsina State Local Government offices in Nigeria: A viable strategy for reducing the prevalence of work related musculo-skeletal disorders. International Journal of Research and Review. www.gkpublication.in E-ISSN: 2349-9788; P-ISSN: 2454-2237

Adedoyin, R. A.; Idowu, B. O.; Adagunodo, R. E. \& Idowu, P. A. (2004). "Musculoskeletal Pain Associated With The Use Of Computer Systems In Nigeria." The Internet Journal of Pain, Symptom Control and Palliative Care. (2004). 3 (2).

Afeidia, A. O. (2006). "Information and Communication Technology - Impact on Secretarial Workers." Journal of Office Management and Technology. Auchi Polytechnic. 1(1), 134.

Aina, M. A. (2003). "Employment Opportunities in Secretarial Education."Voc-Tech Forum. 5(1), 133 - 138.

Akinbinu TR, Mashalla YJ (2013) Knowledge of computer vision syndrome among computer users in the workplace in Abuja, Nigeria. J Physiol Pathophysiology 4: 58-63.

Bakare, W. (2009) in Hope Afoke Orivri "Understanding Ergonomics (1)". Nigerian Compass Newspaper.

Bernacki, E.J., Guidera, J.A., Scharefer, J.A., Lavin, R.A., Tsai, S.P. (1999). An ergonomics program designed to reduce the incidence of upper extremity work related musculoskeletal disorders. Journal of Occupational and Environmental Medicine. 41, 1032 - 1041.

Birbal and Taylor (2004). "Log on to it". China, Pearson Educational Limited.

Buseni, J. (2013). Effects of Information and Communication Technology on Secretaries' Performance in Contemporary Organisations in Bayelsa State, Nigeria. Information and Knowledge Management www.iiste.org ISSN 2224-5758 (Paper) ISSN 2224-896X (Online) 3(5), 87.

Crowl, D. A. (Ed.). (2007). Human factors methods for improving performance in the process industries. John Wiley \& Sons.

Ekstrand, Mari, and Sigrid Damman. (2016) "Front and backstage in the workplace: an explorative case study on activity based working and employee perceptions of control over work-related demands." Journal of Facilities Management 14.2.

Ergonomics (1998) An introduction to nursing informatics. (2nd edn). USA: Springer-Verlag 210-218.

Erwart, E. A. . (2008). "Ergonomics.” Unpublished M.Sc. Lecture Note.

Frymoyer, J. W. \& Mooney, V. (1986). Current concepts review, Occupational Orthopedics Journal. Bone Joint Surg. 68A, 469e474.

Hedge, A. (2000). "Big mouse, a solution to Repetitive Strain Injury." New York Times. 40: 15-16

Jamison, D.T., Breman, J. G., Measham, A.R., Alleyne, G. \& Claeson, M. (2006) Disease control priorities in developing countries, WHO, Geneva.

Juul-Kristensen, B. and Jensen, C. (Accessed 2018). Self-reported workplace related ergonomic conditions as prognostic factors for musculoskeletal symptoms: the "BIT" follow up study on office workers. http://dx.doi.org/10.1136/oem.2004.013920

Khan, R.; Surti, A.; Rehman, R. \& Ali, U. (2012). Knowledge and practices of ergonomics in computer users. JPMA 62: 213-217.

Kumah, D. B.; Akuffo, K. O.; Affram, D. E.; Ankamah, E. \& Osae, E. A. (2016). Ergonomic challenges of 
employees using computers at work in a tertiary institution in Ghana. Optom open access 1: 107. doi:10.4172/omoa.1000107

Microsoft Encarta, (2006). C 1993-2008 Microsoft Corporation.

Microsoft Encarta (2009). C 1993-2008 Microsoft Corporation.

Niu, S. (2010). Ergonomics and occupational safety and health: An ILO perspective Programme on Safety and Health at Work and the Environment. International Labour Organization. 3 March.

Nyland, L. J. \& Grimmer, K. A. (2003). Is undergraduate physiotherapy study a risk factor for low back pain? A prevelance study of LBP in physiotherapy students. BMC Musculoskeletal Disor. 4:22.

Occupational Health and Safety Managers (Nigeria) (2009)

Occupational Safety and Health Administration (2010) US Department of Labour.

Pasmore, W. A. (1988). Designing Effective Organizations, New York, John Wiley. 87-109.

Salik, Y. and Özcan, A. (2004). Work-related musculoskeletal disorders : A survey of physical therapists in IzmirTurkey. 18 August. 5:27 doi:10.1186/1471-2474-5-27

Snook, S.H., (1987). Approaches to replacement testing and selection of workers. Ergonomics. 30, 241 - 247.

Tafese, A; Nega, A; Getasew, D. \& Erku, G (2018). Assessment of Knowledge and Practice of Computer Ergonomics among Secretaries and Data Processing Workers in University of Gondar, Northwest Ethiopia. Journal of Community Med Health Educ. 8(1): 583 DOI: 10.4172/2161-0711.1000583

The Department of Education, Training and the Arts (2008). Hints for Parents/Carers when children are using computer equipment. http://education.qld.gov.au/smartclassrooms/ parents/hints.html\#top

Triano, J. J.; \& Nancy, C. Selby, (2007). "Ergonomics of the Workplace: Overview."

Tuller, D. (2000). "Secretaries Under Siege." Consumer Health Interactive. http://www.ahealthyme. com/topic/secretary.

Wikipedia, (2008). Ergonomics. "http://en.wikipedia.org/wiki/Information_communication_technology" Categories: Communication 25 Voc-Tech Forum . 5(1), $133-138$.

Yekini, N. A. (2014). Information Communication Technology (ICT) [Concepts and Application]Book. SelfDirected \& Collaborative Learning Approach. (1), DOI: 10.13140/RG.2.1.1802.7289 CITATIONS 0 READS 58,481https://www.researchgate.net/publication/297403818_INFORMATION_COMMUNICATION_TEC HNOLOGY_ICT_Concepts_and_Application 